\title{
Bandar Udara Abdulrachman Saleh Malang Menuju Bandar Udara Internasional
}

\author{
Hary Soegiri \\ Sawali
}

\author{
Politeknik Penerbangan Surabaya \\ Jl. Jemur Andayani I/73 Surabaya
}

\begin{abstract}
ABSTRAK
Peningkatan status BUARS (Bandar udara abdurahman saleh) menjadi bandar udara internasional, merupakan perioritas pembangunan Jawa Timur yang bertujuan untuk :Meningkatkan aksesibilitas dan kualitas pelayanan transportasi dan pendidikan, Memperluas lapangan kerja, Meningkatkan percepatan pertumbuhan ekonomi yang berkualitas dan berkelanjutan. Dengan adanya peningkatan status BUARS (Bandar udara abdurahman saleh) menjadi bandara internasional tersebut diharapkan akan dapat memudahkan masyarakat umum dan mahasiswa untuk mengakses transportasi untuk menunjang wilayah Malang Raya sebagai kota Pendidikan dan pariwisata dan juga dapat meningkatkan perekonomian Jawa Timur khususnya Malang Raya. Prediksi penumpang internasional BUARS (Bandar udara abdurahman saleh) pada tahun 2017 berdasarkan perhitungan model regresi akan mencapai 90.002 penumpang, pada tahun 2018 berkisar 97.079 penumpang, tahun 2019 akan mencapai 104.125 penumpang dan prediksi tahun 2020 akan mencapai 111.145 penumpang
\end{abstract}

Kata-Kata Kunci: Malang, Bandar Udara Internasional, aksesbilitas, pelayanan, transportasi.

\section{LATAR BELAKANG}

Pengembangan kebutuhan akan transportasi saat ini berkembang sangat pesat dari tahun ke tahun. Salah satu jenis tranportasi yang cenderung meningkat perkembangannya pada saat ini adalah transportasi udara. Salah satu factor yang penting dalam hal transportasi adalah sarana dan prasarana yang mendukung, dalam hal ini factor keberadaan Bandar udara merupakan yang terpenting di dalam mendukung tranportasi udara. Secara umum, Bandar udara yang memadai adalah Bandar udara yang memenuhi kriteria-kriteria yang memenuhi syarat kenyamanan dan keamanan bagi pihak-pihak yang berkepentingan.

Bandara tidak semata-mata hanya sebagai infrastruktur yang mendukung transportasi udara, akan tetapi Bandar udara dapat berperan penting dalam mendukung pertumbuhan ekonomi daerah. Di Jawa Timur, Bandar udara yang utama adalah Bandara Udara Internasional Juanda Surabaya (BUIJS), yang memiliki peran vital dalam pertumbuhan perekonomian daerah. Masyarakat Jawa Timur pada saat ini cenderung menggunakan BUIJS untuk berpergian keluar daerah, baik domestic maupun internasional. Semakin meningkatnya pertumbuhan ekonomi nasional yang menyentuh pada level 5.4\%, telah menyebabkan masyarakat Jawa Timur melakukan kegiatan ekonomi dengan daerah lain, baik domestic dan internasional. Konsekuensinya adalah jumlah pengguna BUIJS telah jauh melebihi kapasitas normalnya, sehingga hal ini menyebabkan menurunnya kenyamanan pengguna BUIJS dan semakin rendahnya potensi untuk meningkatkan perekonomian daerah.

Salah satu solusi yang diwacanakan oleh Pemerintah Provinsi Jawa Timur untuk mengatasi permasalahan tersebut adalah internasionalisasi Bandar Udara Abdulrachman Saleh (BUARS). Adanya kebijakan untuk internasionalisasi BUARS, diharapkan permasalahan jumlah pengguna BUIJS yang telah jauh melebihi kapasitas normalnya dapat teratasi dan dapat meningkatkan perekonomian Jawa Timur. BUARS berada di Kec. Pakis, Kabupaten Malang Jawa Timur, yang pada awal mulanya merupakan Bandar udara yang dipergunakan untuk militer. Pada tahun 2005, BUARS merupakan tahun pertama digunakan bagi penerbangan sipil, yang dikarenakan sulitnya masyarakat untuk mengakses BUIJS karena adanya lumpur Lapindo. 
Pemilihan BUARS untuk dikembangkan sebagai Bandar Udara Internasional dan sebagai alternative dari BUIJS, telah didasarkan pada beberapa pertimbangan awal yaitu : a) altenatif penerbangan dari bandar udara Juanda, b) berkembangnya perekonomian di wilayah Malang Raya, dan c) pusat pendidikan dan wisata. Kondisi saat ini, jumlah pengguna (pengunjung) dan aktifitas penerbangan sipil di BUARS cenderung stabil, dan jumlahnya tidak sebanyak dibandingkan dengan BUIJS. Hal ini wajar karena sarana dan prasarana dari BUARS tidak sebaik BUIJS. Terbatasnya rute perjalanan udara juga sebagai factor relative rendahnya jumlah penumpang BUARS dibandingkan dengan BUIJS.

Secara teknis, pengembangan BUARS sebagai Bandar Udara Internasional adalah melalui peningkatan sarana dan prasarana Bandar udara yang disesuaikan dengan syarat-syarat yang memenuhi ketentuan sebagai Bandar Udara Internasional. Seiring dengan adanya wacana internasionalisasi BUARS, Pemerintah Provinsi Jawa Timur melalui Dinas Perhubungan Provinsi Jawa Timur mengusulkan adanya peningkatan status BUARS menjadi Bandar Udara Internasional kepada Kementerian Perhubungan. Adanya usulan peningkatan status BUARS tersebut, maka harus perlu diperhatikan juga sarana dan prasarananya. Terdapat beberapa sarana dan prasarana yang telah diusulkan untuk mendukung peningkatan status BUARS menjadi Bandar Udara Internasional, yaitu :

a. Penambahan landasan pacu di BUARS menjadi 3000 meter

b. Menambah jumlah landasan pacu di BUARS menjadi dua landasan pacu

c. Melanjutkan pembangunan gedung terminal keberangkatan di BUARS

\section{Rumusan Masalah}

Adapun rumusan masalah adalah :

1. Bagaimana potensi pasar penerbangan internasional BUARS dan

2. Bagaimana strategi keberlanjutan pasar BUARS dimasa yang akan datang

\section{Tujuan}

Tujuan dari penulisan makalah ini adalah

1. Untuk memberikan gambaran mengenai potensi pasar akan kebutuhan Bandar udara internasional

2. Untuk memberikan masukan kepada pengambil kebijakan dalam rangka pembangunan melalui sektor tranportasi

\section{KONDISI SEKARANG}

Saat ini prasarana yang terdapat di BUARS dalam mendukung operasional adalah : panjang runway yang cukup memadai sepanjang 2250 meter, apron yang dapat menampung 7 pesawat sejenis boeing 727 seri 400-800. Seperti umumnya bandara-bandara lain, sarana BUARS juga telah memadai, saat ini maskapai yang melayani di BUARS ada 5 maskapai antara lain Garuda, Citylink, Sriwijaya, Wing air dan Batik air. Pelayanan utama yang diberikan oleh BUARS adalah penerbangan sipil nasional dengan rute Malang - Jakarta, Malang - Bandung, Malang - Halim Perdana Kusuma, Malang - Denpasar dengan pelayanan pendukung antara lain : telah tersedia taxi bandara yang cukup banyak untuk mengantarkan penumpang dari bandar udara menuju lokasi lain.

Wilayah yang dilayani oleh BUARS meliputi beberapa daerah kabupaten kota disekitar BUARS yaitu Kab/Kota Malang, Kota Batu, Kab/Kota Pasuruan, Kab/Kota Probolinggo, Kab. Lumajang, Kab. Jombang, Kab/Kota Blitar, Kab/Kota Kediri, dan Kab. Tulungagung.

Secara umum dapat dikatakan bahwa jumlah penumpang yang menggunakan BUARS adalah merupakan peralihan sebagian dari jumlah penumpang yang sebelumnya memanfaatkan BUIJS, khususnya yang berasal dari wilayah pelayanan BUARS

Untuk mengetahui potensi demand khususnya penerbangan internasional yang melalui BUARS di masa mendatang maka digunakan prakiraan potensi demand baik penerbangan domestic maupun internasional di BUIJS dan BUARS, dan selanjutnya dihitung berdasarkan proporsi (perbandingan) berapa persen penumpang internasional BUIJS yang diperkirakan akan beralih menggunakan BUARS. Prakiraan potensi demand penerbangan internasional BUIJS menggunakan metode regresi dengan variable regresor adalah tahun. 
Rumus umum regresi adalah

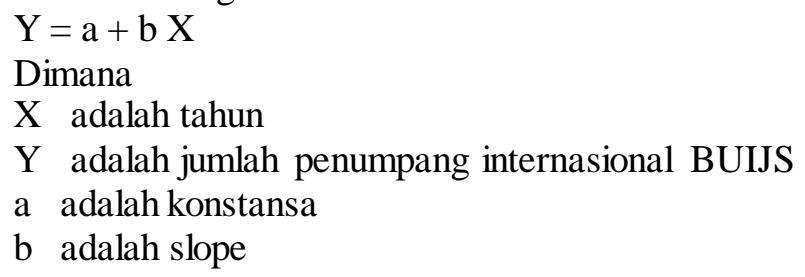

\section{PEMBAHASAN}

Bandar udara internasional adalah Bandar udara yang melayani angkutan langsung para penumpang dan barang dari dan ke luar negeri dan tempat transit untuk menuju ketempat lain. Status BUARS yang saat ini melayani angkutan penumpang dan barang dari dan ke daerah yang merupakan pusat untuk menuju daerah sekitar, telah layak untuk dikembangkan menjadi Bandar udara internasional.

Usulan meningkatan status BUARS tidak hanya dikaji kelayakan dari sisi teknis saja, tetapi juga dianalisis kelayakan dari sisi potensi pasar dari BUARS. Hal ini dapat di lihat dari :

a. Pertumbuhan penduduk kota Malang, baik yang menetap atau sementara (mahasiswa, pekerja,dll).

b. Ekspor import yang terjadi per tahun yg mencapai angka hingga ratusan milyar rupiah

c. Peningkatan tamu hotel baik domestic maupun manca Negara

d. Peningkatan penempatan TKI ke luar negeri yang selalu mengalami kenaikan di wilayah Jawa Timur

e. Tenaga Kerja Asing yang bekerja di wilayah Jawa Timur

$\mathrm{Hal}$ - hal tersebut yang mendasari kebutuhan akan Internasionalisasi BUARS sebagai alternative

Bandar udara Internasional di Jawa Timur dimana pada akhirnya di harapkan akan berdampak secara sistematik pada peningkatan taraf hidup dan perbaikan perekonomian Provinsi Jawa Timur.

Terdapat beberapa fakta yang menjadi dasar bahwa BUARS layak untuk ditingkatkan menjadi Bandar udara internasional antara lain :

1. Tantangan bagi Indonesia dan khususnya Jawa Timur untuk menghadapi ASEAN open sky

Menurut transmedia (2015) dimasa mendatang penerbangan sipil di Indonesia akan menghadapi 4 tantangan yaitu :

a. Pasar penerbangan yang bergeser dari Atlantik ke Asia Pasifik

Menurut wakil Presiden Senior Airbus, Christopher Emerson mengungkapkan dalam 10 tahun belakangan ini penerbangan di Asia Pasifik mengalami pertumbuhan lebih dari 50\% dan akan tumbuh sekitar 200\% lebih dalam kurun waktu 20 tahun kedepan.

b. Penerbangan di Indonesia meningkat cepat

Menurut Chief Executive Officer IATA yaitu Tony Tyler yang juga dikutif oleh Transmedia (2015) mengungkapkan Indonesia akan menjadi pasar terbesar kesembilan di dunia untuk perjalanan

c. Tantangan untuk menghadapi ASEAN Open Sky

Pergeseran pasar global dari pasar Atlantik ke pasar Asia Pasifik, telah mengindikasikan akan terjadi peningkatan pertumbuhan penerbangan yang sangat tinggi dimasa mendatang. Selain itu juga adanya kebijakan ASEAN Open Sky mulai tahun 2015 akan juga semakin meningkatkan tingkat pertumbuhan penerbangan domestic maupun penerbangan luar negeri

2. BUARS sebagai altenatif penerbangan dari BUIJS

BUIJS merupakan Bandar udara tersibuk kedua di Indonesia setelah bandar udara Soekarno Hatta. Terindikasikan bahwa BUIJS sudah melampaui kapasitas maksimalnya. Jumlah penumpang di BUIJS adalah tertinggi kedua setelah Bandar Udara Internasional Soekarno Hatta. Tingginya aktifitas di BUIJS akan mempunyai potensi untuk mengurangi kinerja operasional BUIJS dan mengurangi kenyamanan masyarakat menggunakan BUIJS. Untuk mengatasi potensi masalah yang dihadapi oleh BUIJS di masa mendatang yaitu dengan cara penyediaan alternative Bandar udara yang memiliki sarana dan prasarana yang selevel dengan BUIJS. Sebagai alternatifnya adalah BUARS karena dinilai memiliki letak yang strategis ditengah-tengah wilayah Jawa Timur.

3. Berkembangnya perekonomian di wilayah Jawa Timur dan Malang Raya 
Provinsi Jawa Timur mempunyai peluang besar untuk memiliki pendapatan daerah yang lebih unggul dari daerah lain karena Provinsi Jawa Timur memiliki sumber daya ekonomi yang tidak kalah dengan Provinsi lain. Salah satu mekanisme yang dapat digunakan untuk meningkatkan PDRBnya adalah dengan cara meningkatkan perekonomian daerah.

Salah satu factor pendukung perekonomian daerah adalah meningkatkan dan mempermudah transportasi masyarakat Jawa Timur untuk melaksanakan transaksi ekonomi.

4. Malang Raya merupakan pusat pendidikan dan wisata

BUARS berada di wilayah Malang Raya, merupakan pusat pendidikan dan pusat pariwisata di Jawa

Timur. Berikut merupakan analisa awal dari wilayah Malang Raya :

a. Malang Raya sebagai pusat pendidikan

Pusat pendidikan yang dimaksud adalah cenderung terkonsentrasinya pusat pendidikan tinggi di sekitar Kota Malang. Jumlah pendidikan tinggi yang berada di wilayah Kota Malang lebih tinggi dibandingkan dengan kota-kota lainnya di wilayah Jawa Timur. Jumlah mahasiswa yang semakin banyak dari berbagai macam asal mahasiswa telah menyebabkan naiknya kebutuhan transportasi udara.

b. Malang Raya sebagai pusat pariwisata

Malang Raya juga merupakan salah satu pusat pariwisata di Indonesia, khususnya wilayah Jawa Timur. Adanya kebijakan dari pemerintah pusat yang berusaha untuk meningkatkan peran sector pariwisata dalam kontribusinya untuk meningkatkan pertumbuhan perekonomian nasional, maka Pemerintah Provinsi Jawa Timur juga berupaya untuk meningkatkan pertumbuhan sector pariwisata.

Sudah bukan rahasia umum lagi bahwa sector pariwisata di Malang Raya mendapat respon cukup menarik dari masyarakat Indonesia. Kebutuhan transportasi udara semakin meningkat, hal ini disebabkan oleh frekuensi lalu lintas darat yang meningkat cukup tajam terutama pada hari libur, sehingga BUARS memang benar-benar perlu ditingkatkan menjadi Bandar udara Internasional.

Selain faktor diatas, dapat juga dilihat dari pertumbuhan penduduk di Malang raya. Beberapa data diperoleh bahwa terdapat cukup banyak juga penduduk dari luar wilayah Malang Raya yang bermutasi ataupun berkunjung ke Malang Raya. Tabel 1 menunjukkan perkembangan jumlah penduduk yang berkunjung ke Malang Raya. Meskipun untuk Kota Batu mengalami penurunan, namun secara global penduduk yang berkunjung ke Malang Raya dalam satu tahun mengalami kenaikan sebesar 19,56\%. Pada table 2 menunjukkan perkembangan jumlah penduduk yang bermutasi ke wilayah Malang Raya. Dari tahun 2014 hingga 2015, jumlah penduduk yang bermutasi ke wilayah Malang Raya mengalami kenaikan sbesar $87,76 \%$

Tabel 1 Jumlah Penduduk yang berkunjung ke Malang Raya

\begin{tabular}{|c|l|r|r|}
\hline No & \multicolumn{1}{|c|}{ Malang Raya } & 2014 & \multicolumn{2}{|c|}{2015} \\
\hline 1 & Kota Malang & 18.567 & 19.473 \\
\hline 2 & Kab. Malang & 21.078 & 29.103 \\
\hline 3 & Kota Batu & 3.245 & 2.700 \\
\hline \multicolumn{2}{r}{ Total } & 42.890 & 51.276 \\
\hline
\end{tabular}

Sumber : Kota Malang dalam angka 2015

Kab. Malang dalam angka 2015

Kota Batu dalam angka 2015

Tabel 2 Jumlah Penduduk yang bermutasi ke Malang Raya

\begin{tabular}{|c|c|c|c|c|c|c|}
\hline \multirow{2}{*}{ No } & \multirow{3}{*}{ Malang Raya } & \multicolumn{5}{|c|}{ Tahun } \\
\cline { 3 - 7 } & 2011 & 2012 & 2013 & 2014 & 2015 \\
\hline 1 & Kota Malang & 20.646 & 19.162 & 21.403 & 20.461 & NA \\
\hline 2 & Kab. Malang & NA & NA & 17.807 & 23.808 & NA \\
\hline
\end{tabular}




\begin{tabular}{|l|c|c|c|c|c|c|}
\hline 3 & Kota Batu & 2.932 & 1.567 & 2.675 & NA & NA \\
\hline \multicolumn{2}{|c|}{ Total } & 23.578 & 20.729 & 41.885 & 44.269 & NA \\
\hline
\end{tabular}

Sumber : Kota Malang dalam angka 2015

Kab. Malang dalam angka 2015

Kota Batu dalam angka 2015

Kegiatan eksport impor juga dapat mendukung internasionalisasi BUARS. Kenaikan ekspor Kota Malang cukup signifikan dari \$9.918.653,74 di tahun 2014 naik menjadi \$717.028.480,80. Hanya dalam kurun waktu satu tahun kenaikan ekspor bisa mencapai \$707.109.827,06. Untuk ekspor Kota Malang kenaikan ekspornya tidak melonjak seperti Kabupaten Malang, namun tetap ada kenaikan dari \$271.909.692,00 di tahun 2014 menjadi \$303.731.298,57 di tahun 2015. Kenaikan impor Kota Malang dari \$7.130.209,89 di tahun 2014 naik menjadi \$19.197.285,56 di tahun 2015 .

Sudah diketahui bersama dan bukan rahasia umum lagi, untuk menuju Malang Raya melalui jalan darat terdapat beberapa titik kemacetan bahkan bias stagnant. Hal tersebut merupakan hambatan bagi WNA pengguna BUIJS yang akan menuju ke Malang Raya. Dapat dilihat pada table 3 terjadi penurunan yang cukup signifikan dari 979 orang WNA di tahun 2007 menjadi 212 orang WNA di tahun 2011.

Tabel 3 Jumlah Penduduk menurut kewarganegaraan

\begin{tabular}{|c|c|c|c|c|c|c|c|c|c|c|}
\hline \multirow{3}{*}{$\begin{array}{c}\text { Malang } \\
\text { Raya }\end{array}$} & \multicolumn{10}{|c|}{ Tahun } \\
\hline & \multicolumn{2}{|c|}{2010} & \multicolumn{2}{|c|}{2012} & \multicolumn{2}{|c|}{2013} & \multicolumn{2}{|c|}{2014} & \multicolumn{2}{|c|}{2015} \\
\hline & WNI & WNA & WNI & WNA & WNI & WNA & $\overline{\text { WNI }}$ & WNA & WNI & WNA \\
\hline $\begin{array}{l}\text { Kota } \\
\text { Malang }\end{array}$ & 800.988 & 979 & 835.157 & 979 & 839.543 & 505 & 88.813 & 266 & 892.342 & 212 \\
\hline
\end{tabular}

Sumber : Kota Malang dalam angka 2015

Secara umum dapat disampaikan bahwa keberadaan BUARS adalah untuk melayani potensi angkutan udara dari beberapa wilayah di wilayah penyangga yang sebelumnya dilayani hanya oleh BUIJS. Dengan demikian dapat disimpulkan bahwa keberadaan BUARS adalah seperti peningkatan kapasitas BUIJS yang dikhususkan untuk melayani wilayah penyangganya.

Tabel 4 Jumlah penumpang domestic dan internasional BUIJS dan jumlah penumpang domestic BUARS

\begin{tabular}{|l|l|r|r|r|r|r|}
\hline \multirow{2}{*}{ Tahun } & \multicolumn{2}{|c|}{ BUIJS } & \multicolumn{2}{c|}{ BUARS } & \multicolumn{2}{c|}{ Jumlah } \\
\cline { 2 - 7 } & Domestik & Internasional & Domestik & Internasional & Domestik & Internasional \\
\hline 2010 & 10.643 .428 & 1.232 .113 & 363.573 & 0 & 11.007 .001 & 1.232 .113 \\
\hline 2011 & 12.096 .830 & 1.330 .693 & 463.225 & 0 & 12.560 .055 & 1.330 .693 \\
\hline 2012 & 14.599 .791 & 1.505 .959 & 509.469 & 0 & 15.109 .260 & 1.505 .959 \\
\hline 2013 & 15.839 .857 & 1.822 .690 & 525.725 & 0 & 16.365 .582 & 1.822 .690 \\
\hline 2014 & 15.498 .109 & 1.735 .398 & 626.690 & 0 & 16.124 .799 & 1.735 .398 \\
\hline 2015 & 15.456 .858 & 1.687 .053 & 722.827 & 0 & 16.179 .685 & 1.687 .053 \\
\hline 2016 & 17.651 .183 & 1.832 .661 & 859.878 & 0 & 18.511 .061 & 1.832 .661 \\
\hline
\end{tabular}

Sumber : Otband Wil III \& Bandara Abd. Saleh Malang

Model regresi yang digunakan untuk meramalkan jumlah penumpang domestik (baik yang melalui BUIJS maupun BUARS) adalah sebagai berikut :

$$
\begin{aligned}
& Y 1=-2.196 .803 .534+1.098 .820,679 X \\
& Y 2=-152215138,3+75905 X
\end{aligned}
$$

Dimana 
$\mathrm{X}$ adalah tahun

Y1 adalah jumlah penumpang domestik total (BUIJS + BUARS)

Y2 adalah jumlah penumpang domestik BUARS

Dari rumus di atas, prediksi jumlah penumpang tahun 2017 sd 2020 adalah sebagai berikut :

Tabel 5. Prediksi Jumlah Penumpang Domestik dan Proporsi Penumpang BUARS

\begin{tabular}{|c|c|c|c|}
\hline Tahun & $\begin{array}{c}\text { Prediksi Penumpang } \\
\text { Domestik Total }\end{array}$ & $\begin{array}{c}\text { Prediksi Penumpang } \\
\text { Domestik Buars }\end{array}$ & $\begin{array}{c}\text { Proporsi Penumpang Buars } \\
\text { Dibanding Total }\end{array}$ \\
\hline 2017 & 19.517 .776 & 885.247 & 4.5 \\
\hline 2018 & 20.616 .596 & 961.152 & 4.7 \\
\hline 2019 & 21.715 .417 & 1.037 .057 & 4.8 \\
\hline 2020 & 22.814 .238 & 1.112 .962 & 4.9 \\
\hline
\end{tabular}

Selanjutnya dihitung prediksi jumlah penumpang internasional BUIJS dan berdasarkan proporsi penumpang BUARS disbanding total penumpang maka dapat dihitung prediski jumlah penumpang internasional BUARS yang merupakan potensi demand penumpang internasional BUARS, sebagai berikut :

$$
\mathrm{Y} 3=-195667470,4+97992,296429 \mathrm{X}
$$

\section{Dimana}

$\mathrm{X}$ adalah tahun

Y3 adalah jumlah penumpang internasional BUIJS

Tabel 6. Prediksi Jumlah Penumpang Internasional di BUIJS dan BUARS

\begin{tabular}{|c|c|c|c|}
\hline Tahun & $\begin{array}{c}\text { Prediksi Penumpang } \\
\text { Internasional Buijs }\end{array}$ & $\begin{array}{c}\text { Proporsi Penumpang Buars } \\
\text { Dibanding Total }\end{array}$ & $\begin{array}{c}\text { Prediksi Penumpang } \\
\text { Iternasional Buars }\end{array}$ \\
\hline 2017 & 1.984 .339 & 4,5 & 90.002 \\
\hline 2018 & 2.082 .332 & 4,7 & 97.079 \\
\hline 2019 & 2.180 .325 & 4,8 & 104.125 \\
\hline 2020 & 2.278 .317 & 4,9 & 111.145 \\
\hline
\end{tabular}

Mengingat besarnya potensi penerbangan interbasional melalui BUARS maka pemerintah, baik pusat maupun daerah harus mampu mengambil kebijakan yang dapat mendorong terealisasinya penerbangan langsung internasional ke BUARS. Tanpa kebijakan yang cepat dan te pat maka potensi tersebut tidak dapat diwujudkan dan pada akhirnya peluang untuk mengambil manfaat dari penerbangan internasional menjadi sia-sia.

Yang paling segera dan mendesak untuk ditingkatkan kapasitas pelayanannya adalah runway yang perlu diperpanjang, tersedianya terminal kedatangan yang representative, prasarana bantu untuk kenyamanan penumpang seperti garbarata, aksesibilitas darat yang nyaman dan cepat, dan lain-lain

\section{KESIMPULAN DAN SARAN}

Kesimpulan dari uraian diatas dapat ditarik kesimpulan bahwa BUARS layak dan memiliki potensi yang luar biasa untuk dijadikan bandar udara internasional.

\begin{tabular}{|c|c|}
\hline Tahun & Prediksi Penumpang Internasional \\
\hline 2017 & 90.002 \\
\hline 2018 & 97.079 \\
\hline 2019 & 104.125 \\
\hline 2020 & 111.145 \\
\hline
\end{tabular}


Saran-saran :

1. Meningkatkan sarana dan prasarana BUARS sesuai dengan persyaratan sebagai bandar udara internasional

2. Memperbanyak maskapai penerbangan yang beroperasi di BUARS agar masyarakat dapat memilih maskapai yang dikehendaki

3. Menambah rute penerbangan untuk dipersembahkan ke masyarakat sehingga terdapat banyak pilihan rute baik domestic maupun internasional

\section{DAFTAR PUSTAKA}

Arikunto, Suharsim, Prosedur Penelitian, Rineka Cipta, Jakarta 1989

Undang-undang Penerbangan no 1 tahun 2009

Geospasial Transportasi Udara, Kementerian Perhubungan

Transmedia 2012-2015

BPS 2012-2015

PT. Angkasa Pura I Juanda Surabaya

Otoritas Bandara Wilayah III Surabaya

Bandara Abdulrachman Saleh Malang

Nazir. Moh, Metode Penelitian, Ghalia Indonesia, Jakarta 1983

Salim, Emil, Perencanaan Pembangunan dan Pemerataan PendapatanYayasan Indayu, Jakarta 1980

Pusat Pembinaan dan pengembangan Bahasa, Kamus Besar Bahasa Indonesia, Balai Pustaka, Jakarta 1988

Surachman, Pengantar Penelitian Ilmiah, Tarsito, Bandung, 1978 